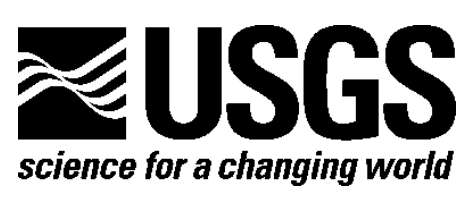

Geology and Geophysics Applied to Groundwater Hydrology at Fort Irwin, California

David C. Buesch, Editor

\title{
Generalized Surficial Geologic Map of the Fort Irwin Area, San Bernardino County, California
}

By David M. Miller, Christopher M. Menges, and David J. Lidke

Open-File Report 2013-1024-B

U.S. Department of the Interior

U.S. Geological Survey 


\section{U.S. Department of the Interior SALLY JEWELL, Secretary}

\section{U.S. Geological Survey \\ Suzette M. Kimball, Acting Director}

U.S. Geological Survey, Reston, Virginia: 2014

For more information on the USGS—-the Federal source for science about the Earth, its natural and living resources, natural hazards, and the environment-visit http://www.usgs.gov or call 1-888-ASK-USGS (1-888-275-8747)

For an overview of USGS information products, including maps, imagery, and publications, visit http://www.usgs.gov/pubprod

To order this and other USGS information products, visit $h$ ttp://store.usgs.gov

Any use of trade, firm, or product names is for descriptive purposes only and does not imply endorsement by the U.S. Government.

Although this information product, for the most part, is in the public domain, it also may contain copyrighted materials as noted in the text. Permission to reproduce copyrighted items must be secured from the copyright owner.

Suggested citation:

Miller, D.M., Menges, C.M., and Lidke, D.J., 2014, Generalized surficial geologic map of the Fort Irwin area, San Bernardino County, California, chap. B of Buesch, D.C., ed., Geology and geophysics applied to groundwater hydrology at Fort Irwin, California: U.S. Geological Survey Open-File Report 2013-1024, 11 p., scale 1:100,000, http://dx.doi.org/10.3133/ofr20131024B. 


\section{Contents}

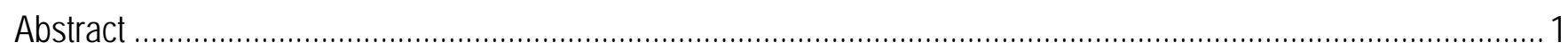

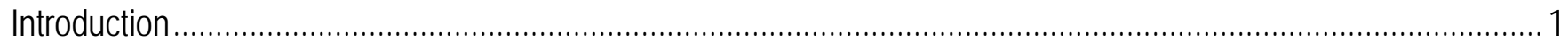

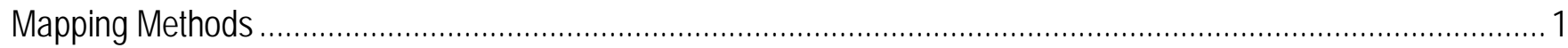

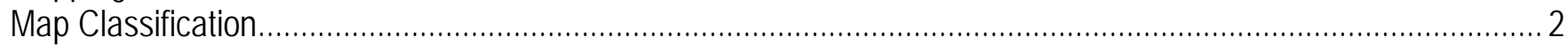

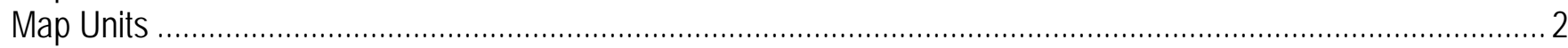

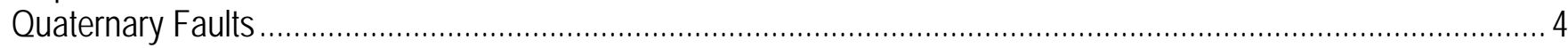

Acknowledgments

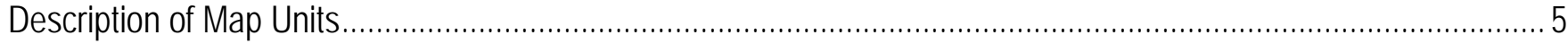

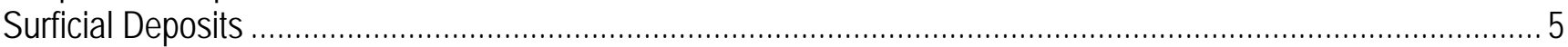

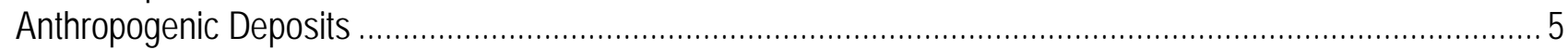

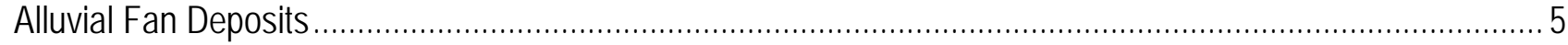

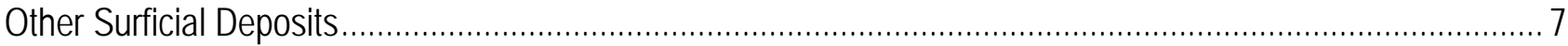

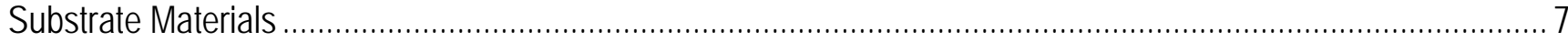

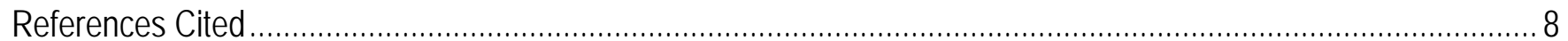

\section{Figures}

1. Generalized fault map for the Fort Irwin area on hillshade base map.................................................. 11

\section{Supplemental Data}

[Available online only at http://pubs.usgs.gov/of/2013/1024/b/.]

1. Map sheet

2. Geodatabase 


\title{
Generalized Surficial Geologic Map of the Fort Irwin Area, San Bernardino County, California
}

\author{
By David M. Miller, Christopher M. Menges, and David J. Lidke
}

\begin{abstract}
The geology and landscape of the Fort Irwin area, typical of many parts of the Mojave Desert, consist of rugged mountains separated by broad alluviated valleys that form the main coarse-resolution features of the geologic map. Crystalline and sedimentary rocks, Mesozoic and older in age, form most of the mountains with lesser accumulations of Miocene sedimentary and volcanic rocks. In detail, the area exhibits a fairly complex distribution of surficial deposits resulting from diverse rock sources and geomorphology that has been driven by topographic changes caused by recent and active faulting. Depositional environments span those typical of the Mojave Desert: alluvial fans on broad piedmonts, major intermittent streams along valley floors, eolian sand dunes and sheets, and playas in closed valleys that lack through-going washes. Erosional environments include rocky mountains, smooth gently sloping pediments, and badlands in readily eroded sediment. All parts of the landscape, from regional distribution of mountains, valleys, and faults to details of degree of soil development in surface materials, are portrayed by the surficial geologic map. Many of these attributes govern infiltration and recharge, and the surface distribution of permeable rock units such as Miocene sedimentary and volcanic rocks provides a basis for evaluating potential groundwater storage. Quaternary faults are widespread in the Fort Irwin area and include sinistral, east-striking faults that characterize the central swath of the area and the contrasting dextral, northwest-striking faults that border the east and west margins. Bedrock distribution and thickness of valley-fill deposits are controlled by modern and past faulting, and faults on the map help to identify targets for groundwater exploration.
\end{abstract}

\section{Introduction}

This geologic map covers an area centered on the National Training Center, Fort Irwin, (herein called Fort Irwin), San Bernardino County, California. The map was prepared to show the distribution and characteristics of surficial deposits, as well as the relations of Quaternary units to bedrock exposures, as an aid to discovering and modeling groundwater resources. The map also shows the distribution of young faults, which can be used for evaluating earthquake hazards as well as better understanding groundwater flow. This report describes the contents of the 1:100,000-scale generalized geologic map and how it was made.

\section{Mapping Methods}

This map was compiled from the detailed surficial geologic maps of the Fort Irwin basin (Yount and others, 1994), Coyote Lake basin (Dudash, 2006), and limited unpublished detailed mapping by 
Miller. The remainder was mapped at the scale of 1:100,000 (with greater detail in part as described in the next section) by standard field methods and interpretation of remote-sensing images, including aerial photography and Landsat 7 data. Field methods included examining the geomorphology, surface and internal features, and soil development of surficial deposits. Mapped geology was transferred from aerial photographs to GIS by heads-up digitizing, using mosaics of digital orthophotograph quadrangles as base maps. Digitizing was conducted at screen scales of 1:20,000 to 1:35,000 to provide location accuracy. Part of the map was published previously (Amoroso and Miller, 2012). Bedrock geology was compiled from Byers (1960), McCulloh (1960), Jennings and others (1962), Brady (1984, 1986), Spencer (1990), Schermer and others (1996), Workman and others (2002), and unpublished mapping by Troxel and Butler.

\section{Map Classification}

Mapping followed the approaches presented by Yount and others (1994) that describe surficial deposits according to a matrix of age and depositional process, a scheme that has been applied widely in the Mojave Desert region (compare to Menges and others, 2001). Many of the criteria for age assignment follow from McFadden and others (1989) and Reheis and others (1989). Unit symbols reflect this breakdown into age and process. Map units are generalized from the scheme that Amoroso and Miller (2012) and Miller (2012) used in 1:100,000-scale maps of surficial geology of the northern Mojave Desert. The generalized map units include several that describe the most abundant deposits, alluvial fan deposits, and a few more that describe deposits of other origins. A total of ten deposit types are shown, as well as a map unit that depicts heavily disturbed area. Mountainous areas underlain by bedrock with very thin hillslope materials are designated by ten generalized bedrock units that reflect weathering properties, given in the map unit descriptions. Areas mapped as pediment in the source maps are designated by the underlying bedrock.

The geologic map database for this report was assembled from parts of three databases of surficial geologic materials at intermediate scales: (1) Amoroso and Miller (2012; Cuddeback Lake quadrangle, 1:100,000 scale), (2) Miller and Lidke (unpub. map of the Soda Mountains quadrangle, 1:100,000 scale), and (3) Menges (unpub. map of the Owlshead Mountains quadrangle, 1:65,000 scale). The databases of map units were merged and consolidated to simplify the presentation to the most relevant units for hydrogeology. Generalization was accomplished mainly by grouping map units to emphasize the most abundant deposits and the shallowest deposits, as well as to combine categories of like units. The resulting classification emphasizes material properties rather than geomorphic processes. Faults were extracted from the three databases and compiled in a separate feature class. Faults are displayed on the map by location confidence instead of other characteristics, such as recency of rupture, certainty of existence, and kinematics. In a few places, the extracted faults represent locations known from ruptures in buried materials that are not displayed on this map, but were part of the map unit designation on the source map. As a result, a few faults may appear to cut Holocene materials when they actually cut underlying Pleistocene materials.

\section{Map Units}

This section briefly describes the surficial and bedrock map units, with special regard to their hydrologic properties. Bedrock older than Cenozoic is diverse and widespread, mainly cropping out in the mountains of the Fort Irwin area but also exposed in pediments and in isolated small pushup blocks along major strike-slip faults. The bedrock ranges in age from middle Proterozoic to Mesozoic 
(Schermer and others, 1996). Although exposed in few places, schist and phyllite (unit sc), quartzite and sandstone (unit sl), dolomite and limestone marble (unit ca), and diverse mixed metamorphic rocks (unit $\mathrm{mr}$ ) provide fundamental knowledge about the original late Proterozoic to early Mesozoic depositional facies and the subsequent metamorphism and faulting of the miogeoclinal and eugeoclinal assemblages (Miller and others, 1995; Schermer and others, 1996). Especially widespread metamorphic rocks in the Soda, Avawatz, and eastern Granite Mountains are diverse metavolcanic rocks probably of Jurassic age (Grose, 1959; Schermer and Busby, 1994; Schermer and others, 1996; Pavlis and others, 1998).

Mesozoic plutonic rocks (units $\mathrm{mp}, \mathrm{fp}$, and fpg) ranging from gabbro and diorite to silicic muscovite granite are widespread. Mafic rocks predominate in an earlier Jurassic suite of plutons, and felsic rocks predominate in a later Cretaceous suite of plutons. Triassic intermediate-composition rocks are also found in the southwest near Superior Lake (Miller and others, 1995). Felsic plutonic rocks in many places form grus (unit fpg) as a result of grain-by-grain weathering, resulting in both distinctive landforms and derivative surficial deposits.

Miocene sedimentary and volcanic rocks were deposited across eroded crystalline rocks in a series of shallow basins and as volcanic edifices. Exposures of Miocene sedimentary rocks (unit pc) mostly lie in a belt across eastern Fort Irwin that passes from the northeast in the Avawatz Mountains southward to the Alvord Mountain area (Grose, 1959; Byers, 1960; Spencer, 1990; Sobieraj, 1994; Schermer and others, 1996; Pavlis and others, 1998). Smaller exposures occur farther west in Fort Irwin and, in places, are interbedded with volcanic rocks. Rocks are principally alluvial fan and big-stream fluvial deposits that range from extremely coarse rock-avalanche breccia to conglomerate, sandstone, and siltstone. Distal alluvial fan and fluvial deposits interfinger with lacustrine deposits of early and middle Miocene age in several basins (Sobieraj, 1994; D. Buesch, written commun., 2014), especially in southern exposures (Byers, 1960). Basinal sequences in many places contain a few volcanic flows or ash-fall tuffs that are used to date deposits (for example, Byers, 1960; Spencer, 1990; Schermer and others, 1996). Miocene volcanic rocks are distinguished on the map in a few areas with thick sequences, including mafic andesite and basalt flows (unit mv) in the Alvord Mountains and intermixed felsic rhyodacite to rhyolite (unit fv) and mafic volcanic rocks northwest of Bicycle Lake to the west limit of the map. The latter volcanic complex is part of an early to middle Miocene dome and flow field named the Eagle Crags volcanic field by Sabin (1994).

Alluvial-fan and valley-axis alluvial deposits are by far the most widespread surficial deposits of the Fort Irwin area. They form along mountain flanks, stretching basinward to low-gradient valley bottoms. They range in age from modern to Pliocene, although most chronology is provided by soilsgeomorphic methods (for example, Reheis and others, 1989) and uncertainty exists in precise ages of deposits. Soils range from barely noticeable peds to strongly developed Av, B, and calcic horizons (units Qya, Qia, and Qoa). Corresponding changes in surface characteristics, from bar-and-swale topography to flat with desert pavements and then to deeply dissected, also aid in determining the relative chronology of deposits (McFadden and others, 1989). The oldest alluvial fan deposits (unit QToa) lack associated soils and typically are out of place with respect to upland sources, indicating that they significantly predate the middle Pleistocene deposits of unit Qoa. In a few places, these oldest alluvial deposits contain datable material that indicates they are early Quaternary and Pliocene in age (Miller and Yount, 2002; Miller and others, 2011). They may be significant as water-bearing units. Grus-dominated versions of the alluvial fan deposits (units Qyag and Qiag) have unique characteristics such as inconsistently developed soils, lack of dissection, and finer grain size.

Other surficial deposits are not widely distributed but hold special significance in many cases. Eolian sand (unit Qe) forms sheets, dunes, and ramps that are especially abundant downwind of prolific sources such as southern Death Valley, Coyote Lake, Superior Lakes, the Cronise Lake area, and east of 
Red Pass Lake (fig. 1). Eolian sand is present over much larger areas as minor components of the landscape and as admixtures to alluvial fan deposits (for example, Amoroso and Miller, 2012), but these mixed deposits are not represented in the generalized map of this report. Playa deposits mark the lowest points of internally drained basins where poorly sorted silt, sand, and clay collect. Most playas (unit Qp) are dry, with deep water tables, but West Cronise Lake and parts of Coyote Lake have shallow groundwater and are discharging, or wet, playas. Groundwater discharge deposits (unit Qg) that formed at modern springs and marshes are present in several places, and past discharge sites are indicated by older deposits. The deposits typically are pale in color and fine grained, consisting of fine sand, silt, and clay, all carbonate-rich, and are significant because they mark past positions of the water table. Lacustrine deposits (unit Ql) are relic from past wetter conditions, when lakes Manley (southern Death Valley) and Manix (Mojave River Valley) persisted. In addition, fine sandy deposits ringing Superior Lakes are probably from past lakes (Amoroso and Miller, 2012). Lacustrine deposits range from clayrich basin-center materials to sand and gravel formed at and near shorelines.

\section{Quaternary Faults}

Faults that ruptured Quaternary deposits are recognized through much of Fort Irwin and adjoining areas. The Garlock Fault Zone represents a major tectonic boundary (fig. 1) that terminates in the Avawatz Mountains in the northeastern corner of the map but continues hundreds of kilometers to the west and southwest. This structure is the single largest fault zone in the map area and forms a tectonic boundary between the main array of sinistral faults to the south and several regional dextral faults and a few subsidiary sinistral faults in southern Death Valley, southern Panamint Valley, and the southern Owlshead Mountains to the north. Sinistral faults make up the Garlock Fault Zone and also lie south of the Garlock Fault through the heart of Fort Irwin. The Silurian Valley probably is also a major boundary because it is a major structural downwarp and because Quaternary faults mainly lie west of it (Miller and others, 2007b).

Recency of fault rupture, an important criterion for earthquake hazards, is fairly complex through the Fort Irwin area (Miller and others, 2007a). In central Fort Irwin, faults do not appear to cut Holocene deposits (Schermer and others, 1996; Pavlis and others, 1998; Miller and Yount, 2002; Miller and others, 2007a). However, Holocene fault scarps are common in the active fault and fold system associated with the eastern Garlock Fault Zone (Clark, 1972; McGill and Sieh, 1991; McGill, 1994a,b), the Southern Death Valley Fault Zone (Wills, 1989a,b; Klinger, 1999; Green, 2009), East Goldstone Lake Fault, Paradise Fault Zone, and Cave Mountain Faults (fig. 1; Miller and others, 2007a). Holocene surface displacements also were identified during the course of unpublished mapping by Menges along the Owlshead Lake Fault, and possibly along strands of the southern Panamint Fault and thrust faults of the northeastern Avawatz Mountains.

Generalized faults are classified on figure 1 with colors coded to primary slip mode: sinistral (left lateral), dextral (right lateral), oblique slip, and thrust. Slip mode was determined from field evidence, published studies, and inferences from geophysical data (Langenheim and Jachens, this volume, chap. I; Jachens and Langenheim, this volume, chap. H). Figure 1 illustrates that much of the central Fort Irwin area forms a domain of east-striking sinistral faults, whereas northwest-striking dextral faults frame the east and west sides. Oblique slip faults in many places strike nearly north and lie in a broad zone of interaction between the sinistral and dextral domains. Many of the oblique slip faults show combinations of dextral and normal slip, but a few are dextral-reverse. This central area is bounded on the north by the eastern section of Garlock Fault Zone, where many fault strands display structural or topographic evidence for oblique slip, commonly sinistral with reverse components. 
Thrust faults are especially prominent in the map area as range-bounding structures along the northeast side of the Avawatz Mountains (Miller and others, 2007b) but are also notable along the northwest side of the Tiefort Mountains and a few other places. These thrust faults are included in the fault feature class. A second class of thrust faults also developed as secondary structures that form the structural boundaries of transpressive zones of contraction and uplift, commonly related to positive flower structures, along major translational faults. These are labeled as "blind thrusts” and are prominent along the southern Death Valley and eastern Garlock Faults. Most of the blind thrust faults shown in figure 1 are identified at the surface on the basis of associated fault-related folds or steeply dipping fault-rotated strata, and the line symbol for the blind thrusts actually lies above the buried fault. Because the blind thrusts are mapped differently than other faults, they are separated from other faults in the database and given a distinct line marker on the map.

The strike-slip faults exhibit surface traces that are too complex in detail to represent at the scale of the map and consist of several subparallel fault strands commonly associated along strike with gaps, overlap zones, deflections or bends in orientation, and en-echelon stepovers. The width and complexity of the fault deformation is especially prominent near the terminations of fault zones and in areas where faults with differing slip sense intersect. Vertical deformation such as sagged areas and pushup blocks are common along many of these faults. As result, various sections of a given fault such as the eastern Garlock Fault Zone may be associated with subsiding basins in zones of transtensional stepovers (for example, Leach Lake basin) that transition to areas of range uplift near restraining bends or areas of fault intersection (for example, the western Avawatz Mountains). Many examples of sags and uplifts, but on scales of a few kilometers, occur in the Nelson Lake area.

\section{Acknowledgments}

We thank several colleagues for sharing data and ideas that contributed to this report: Paul Bedrosian, David Buesch, Vicki Langenheim, Geoff Phelps, Marith Reheis, Bob Reynolds, Liz Schermer, and Jim Yount. Many more individuals contributed valuable information by helping in the field and lab. Reviews by David Buesch, Tracey Felger, and Kevin Schmidt improved early versions of this manuscript and are greatly appreciated. We gratefully acknowledge financial support from Fort Irwin.

\section{DESCRIPTION OF MAP UNITS}

\section{SURFICIAL DEPOSITS}

\section{ANTHROPOGENIC DEPOSITS}

$\mathrm{ml} \quad$ Made land (Holocene) — Material moved for construction purposes that obscures sufficiently large areas to make landforms and deposits difficult to identify

\section{ALLUVIAL FAN DEPOSITS}

Qya Young alluvial fan deposit (Holocene and latest Pleistocene)—Deposits of active and abandoned alluvial fans, ephemeral stream channels, and valley-axis lowlands. Composed of poorly sorted sand and gravel. Loose to slightly compact. Generally weakly developed or no desert pavement. Weak to no varnish on clasts. No soil or weakly developed soil, expressed as incipient to weak sandy Av horizon and weak cambic horizon; stage I or no calcic soil 
(calcic stages follow Gile and others, 1966). Fairly rough surface topography in much of fan with active or remnant bar and swale topography. Moderately to sparsely vegetated

Qyag Young alluvial fan deposit composed of grus-Sand and fine gravel from granitic sources that weather to grus. Surface undulating and smooth; little channel dissection. Soils are immature; pavements and Av horizon rare. Unit is common downslope of Cretaceous granite outcrops

Qia Intermediate alluvial fan deposit (late to middle Pleistocene)_Alluvial fan and ephemeral stream deposits characterized by surfaces that have been abandoned for tens of thousands of years. Composed of poorly sorted sand and gravel. Loose to compact. Characterized by moderately- to welldeveloped desert pavement with moderate to strong varnish on clasts on flat smooth fan surface that is partly incised by narrow channels. Well-developed platy Av horizon composed of silt, very fine sand, and clay. Moderately to strongly developed Bt horizon and Stage I+ to III+ calcic horizon. Generally distinguished on aerial photographs by lack of vegetation, dark varnish, and smooth surface with deeply incised active channels. Pavement, varnish, and Av horizon subdued to absent at high altitudes (above $1,100 \mathrm{~m}$ ); Bt horizon thicker at high altitude; calcic horizon thin. Very sparsely vegetated, but greater vegetative cover at high altitude

Qiag Intermediate alluvial fan deposit composed of grus - Sand and fine gravel from granitic source that weathers to grus. Surface is broadly undulating and intermittently active. Deposit has poorly developed Av and Bt horizons, and calcic horizon is present but variably developed

Qoa Old alluvial fan deposit (middle to early Pleistocene)_Alluvial fan deposits characterized by degraded remnants of abandoned surfaces forming bouldery ridges. Compact to cemented. Commonly forms pale-colored ballenas above active washes in upper parts of alluvial fans near mountain fronts. Forms rounded, deeply dissected terrane with little or no remnant depositional geomorphology; a few meters to tens of meters higher than surrounding deposits. Many clasts on surface made up of disaggregated pieces of calcic horizon, contributing to pale appearance on aerial photographs. Most upper soil horizons stripped off by erosion but commonly has superimposed weak soils developed directly on calcic horizon. Locally has remnant varnished pavement clasts on the surface with very thin or absent Bt horizon, suggesting the surface once had pavement characteristics that have since been eroded. Stage IV and greater calcic horizons 2-6 m thick. Contains Bishop Ash ( 770 $\mathrm{ka}$ ) in exposures of southern Death Valley and in Mojave National Preserve (Miller, 2012). Moderately vegetated

QToa Extremely old alluvial fan deposit (early Pleistocene to Pliocene)—Deeply eroded alluvial fan and river deposits characterized by no remnants of abandoned surfaces and no intact soil horizons. Compact, bouldery. Forms deeply dissected terrane with little or no remnant depositional geomorphology; deposits generally did not form in present topography, as indicated by source directions or clast composition. May have several sets of buried paleosols. 
Contains 3.5 Ma ash in central Fort Irwin and Alvord Mountain (Miller and Yount, 2002). Moderately vegetated

\section{OTHER SURFICIAL DEPOSITS}

Qe Eolian sand deposit (Holocene and Pleistocene)_Eolian sand deposits composed of moderately sorted to well-sorted sand. Ranges from active and loose to older, inactive sand with soils. Forms dune, ramp, and sheet deposits, in many cases near source playa deposits

Qp Playa deposit (Holocene) - Dry lake deposits of vaguely bedded, poorly sorted, silt, clay, and sand, in most cases actively receiving sediments within the last few decades. Intermittently ponded. Includes salty discharging playa deposits at West Cronise Lake and parts of Coyote Lake. Generally flat surface, sparse to no vegetation, although supports shrubs in sandy facies near margin of playa. Form at valley bottoms. Generally pale color on aerial photographs

Qg Groundwater-discharge deposit (Holocene and Pleistocene)—Silt and fine sand, generally white to pale gray in color, commonly with significant calcium carbonate. Loose to compact. Active deposits form in moist zone of groundwater discharge as spring mounds or wetlands with abundant vegetation (Quade and others, 1995). Abandoned deposits commonly form light-colored flat areas or dissected badlands (Pigati and others, 2011). As mapped, locally includes deposits of Pliocene age

QI Lacustrine deposit (Holocene and Pleistocene) —Fine sand, silt, and clay; thin bedded to massive, generally well sorted. Coarse sand and gravel at margins of some former lakes. Sparsely vegetated to barren

\section{SUBSTRATE MATERIALS}

[Buried rock and partly consolidated materials that underlie pediment and hillslope veneers. Ages range from Pliocene to Proterozoic. Substrate materials are subdivided based on weathering characteristics and erosional products]

ca Carbonate rocks - Carbonate-mineral rocks, such as marble, dolomite, and limestone. Commonly weathers to silt

fp Felsic plutonic rocks - Plutonic rocks with common quartz ( $\left.>\sim 68 \% \mathrm{SiO}_{2}\right)$, such as granite and granodiorite. Weathers to rocky deposits

fpg Felsic plutonic rocks that weather to grus-Mostly Cretaceous in age. Weathered materials are chiefly quartz, feldspar, and micas of sand and fine gravel size

fv Felsic volcanic rocks - Volcanic rocks greater than about $68 \% \mathrm{SiO}_{2}$, such as rhyolite, rhyodacite, and felsite. Includes flows and ejecta. Dome-margin facies and highly fractured flows may store groundwater. Rocky weathered materials and altered tuffs may be clay-rich

mp Mafic plutonic rocks-Plutonic rocks with little quartz ( $\left.<\sim 68 \% \mathrm{SiO}_{2}\right)$, such as gabbro, diorite, and monzodiorite. Rocky weathered materials are rich in feldspar, amphiboles, and micas

mv Mafic volcanic rocks-Volcanic rocks less than about $68 \% \mathrm{SiO}_{2}$, such as dacite, andesite, and basalt. Includes flows and ejecta. Laterally extensive mafic 
volcanic flows may conduct and store groundwater. Rocky weathered materials are clay rich; alluvial fans with mafic volcanic source commonly are densely mantled by darkly varnished boulders

$\mathrm{mr} \quad$ Metamorphic rocks-Metamorphic rocks of mixed lithology, such as gneiss, migmatite, and structurally mixed rocks. Includes metavolcanic rocks of probable Mesozoic age

pc Partly consolidated materials-Moderately to weakly consolidated sedimentary deposits such as shale, siltstone, sandstone, and conglomerate; locally includes volcanic rocks or highly altered rocks. Depositional environments range widely, mirroring modern environments, but mostly represent alluvial fan and big-stream fluvial environments. Typically Tertiary in age. Includes the Pickhandle, Clews, Spanish Canyon, Barstow, Avawatz, and Military Canyon Formations. May form badland topography. Weathered materials are enriched in silt and clay

sl Siliciclastic rocks-Silicic sedimentary and metamorphic rocks, such as sandstone and quartzite, shale, and siltstone. Weathered materials are common quartz with subordinate silt and clay

Sc Schistose rocks_-Schist and other metamorphic rocks with abundant mica. Weathered materials are silt and clay

\section{References Cited}

Amoroso, L., and Miller, D.M., 2012, Surficial geologic map of the Cuddeback Lake 30' x 60' quadrangle, San Bernardino and Kern Counties, California: U.S. Geological Survey Scientific Investigations Map 3107, scale 1:100,000, 31 p.

Brady, R.H., III, 1984, Cenozoic geology of the northeastern Avawatz Mountains in relation to the intersection of the Garlock and Death Valley fault zones, San Bernardino County, California: Davis, University of California, Ph.D. Dissertation, 292 p.

Brady, R.H., III, 1986, Stratigraphy and tectonics of the northern Avawatz Mountains at the intersection of the Garlock and Death Valley fault zones, San Bernardino County, California-A field guide, in, Troxel, B.W., ed., Guidebook, Quaternary tectonics of southern Death Valley: Friends of the Pleistocene Pacific Cell, p. 1-12.

Byers, F.M., 1960, Geology of the Alvord Mountain quadrangle, San Bernardino County, California: U.S. Geological Survey Bulletin 1089-A, 71 p., scale 1:62,500.

Clark, M.M., 1972, Map showing recently active breaks along the Garlock and associated faults, California: U.S. Geological Survey Miscellaneous Geologic Investigations Map I-741, scale $1: 24,000,5$ sheets.

Dudash, S.L., 2006, Preliminary surficial geologic map of a Calico Mountains piedmont and part of Coyote Lake, Mojave Desert, San Bernardino County, California: U.S. Geological Survey Open-File Report 06-1090, 48 p. pamphlet, scale 1:24,000.

Gile, L.H., Peterson, F.F., and Grossman, R.B., 1966, Morphological and genetic sequences of carbonate accumulation in desert soils: Soil Science, v. 101, p. 347-360.

Green, H.L, 2009, Neotectonic investigation of the southern Death Valley fault zone, southeastern California: San Francisco State University, M.S. thesis, 152 p., scale 1:12,000.

Grose, T., 1959, Structure and petrology of the northeast part of the Soda Mountains, San Bernardino County, California: Geological Society of America Bulletin, v. 70, no. 12, p. 1509-1548. 
Jennings, C.W., Burnett, J.L., and Troxel, B.W., 1962, Geologic map of California-Trona sheet: California Division of Mines and Geology, scale 1:250,000.

Klinger, R.E., 1999, Tectonic geomorphology along the Death Valley fault system-Evidence of recurrent late Quaternary activity in Death Valley National Park, in, Slate, J.L., ed., Proceedings of conference on status of geologic research and mapping, Death Valley National Park: U.S. Geological Survey Open-File Report 99-153, p. 132-140.

McCulloh, T.H., 1960, Geologic map of the Lane Mountain quadrangle, California: U.S. Geological Survey Open-File Report, scale 1:62,500.

McFadden, L.D., Ritter, J.B., and Wells, S.G., 1989, Use of multiparameter relative-age methods for age estimation and correlation of alluvial fan surfaces on a desert piedmont, eastern Mojave Desert, California: Quaternary Research, v. 32, p. 276-290.

McGill, S.F., 1994a, Holocene slip rate of the easternmost Garlock fault, Avawatz Mountains, California [abs.]: San Bernardino County Museum Association Quarterly, v. 41, no. 3, p. 24. McGill, S.F., 1994b, Neotectonics of the easternmost Garlock fault in the Avawatz Mountains, in Reynolds, R.E, ed., Off limits in the Mojave Desert: San Bernardino County Museum Association Special Publication 94-1, p. 96-100.

McGill, S.F., and Sieh, K., 1991, Surficial offsets on the central and eastern Garlock Fault associated with prehistoric earthquakes: Journal of Geophysical Research, v. 96, p. 21, 597-21,621.

Menges, C.M., Taylor, E.M., Workman, J.B., and Jayko, A.S., 2001, Regional surficial-deposit mapping in the Death Valley area of California and Nevada in support of ground-water modeling, in Machette, M.N., Johnson, M.L., and Slate, J.L, eds., Quaternary and late Pliocene geology of the Death Valley region-Recent observations on tectonics, stratigraphy, and lake cycles-Pacific cell, Friends of the Pleistocene Field Trip, February 17-19: U. S. Geological Survey Open-File Report 01-51, p. H151H166.

Miller, D.M., 2012, Surficial geologic map of the Ivanpah 30' x 60' quadrangle, San Bernardino County, California, and Clark County, Nevada: U.S. Geological Survey Scientific Investigations Map 3206, scale 1:100,000, $14 \mathrm{p}$.

Miller, D.M., Dudash, S.L., Green, H.L., Lidke, D.J., Amoroso, L., Phelps, G.A., and Schmidt, K.M., 2007a, A new Quaternary view of northern Mojave Desert tectonics suggests changing fault patterns during the late Pleistocene, in Miller, D.M., and Valin, Z.C., eds., Geomorphology and tectonics at the intersection of Silurian and Death Valleys, southern California: U.S. Geological Survey Open-File Report 2007-1424, p. 157-171.

Miller, D.M., Menges, C.M., and McMackin, M.R., 2007b, Geomorphology and tectonics at the intersection of Silurian and Death Valleys, southern California-Field trip road log, in Miller, D.M., and Valin, Z.C., eds., Geomorphology and tectonics at the intersection of Silurian and Death Valleys, southern California: U.S. Geological Survey Open-File Report 2007-1424, p. 7-49.

Miller, D.M., Reheis, M.C., Wan, E., Wahl, D.B., Olson, H., 2011, Pliocene and early Pleistocene paleogeography of the Coyote Lake and Alvord Mountain area, Mojave Desert, California, in Reynolds, R.E., ed., The incredible shrinking Pliocene: Fullerton, California State University, Desert Studies Consortium, p. 53-67.

Miller, D.M., and Yount, J.L., 2002, Late Cenozoic tectonic evolution of the north-central Mojave Desert inferred from fault history and physiographic evolution of the Fort Irwin area, California: Geological Society of America Memoir 195, p. 173-197.

Miller, J.S., Glazner, A.F., Walker, J.D., and Martin, M.W., 1995, Geochronologic and isotopic evidence for Triassic-Jurassic emplacement of the eugeoclinal allochthon in the Mojave Desert region, California: Geological Society of America Bulletin, v. 107, p. 1441-1457. 
Pavlis, T.L., Serpa, L., Troxel, B., Dean, M., Hartman, T., and Rodosta, T., 1998, Late Cenozoic deformation in eastern Fort Irwin and its significance for the tectonic history of the Garlock fault system, in Reynolds, R.E., ed., San Bernardino County Museum Association Quarterly, v. 45, no. 2, p. 77-83.

Pigati, J.S., Miller, D.M., Bright, J.E., Mahan, S.A., Nekola, J.C., and Paces, J.B., 2011, Chronology, sedimentology, and microfauna of groundwater discharge deposits in the central Mojave Desert, Valley Wells, California: Geological Society of America Bulletin, v. 123, p. 2224-2239.

Quade, J., Mifflin, M.D., Pratt, W.L., McCoy, W., and Burckle, L., 1995, Fossil spring deposits in the southern Great Basin and their implications for changes in water-table levels near Yucca Mountain, Nevada, during Quaternary time: Geological Society of America Bulletin, v. 107, p. 213-230.

Reheis, M.C., Harden, J.W., McFadden, L.D., and Shroba, R.R., 1989, Development rates of late Quaternary soils, Silver Lake playa, California: Soil Science Society of America Journal, v. 53, p. 1127-1140.

Sabin, A.E., 1994, Geology of the Eagle Crags volcanic field, northern Mojave Desert, China Lake Naval Air Weapons Station, California: Golden, Colorado School of Mines, Ph.D. dissertation, 209 p.

Schermer, E.R., and Busby, C.J., 1994, Jurassic magmatism in the central Mojave Desert-Implications for arc paleogeography and preservation of continental volcanic sequences: Geological Society of America Bulletin, v. 106, p. 767-790.

Schermer, E.R., Luyendyk, B.P., and Cisowski, S., 1996, Late Cenozoic structure and tectonics of the northern Mojave Desert: Tectonics, v. 15, p. 905-932.

Sobieraj, J.A., 1994, Sedimentology and tectonics of Tertiary fan deposits, Fort Irwin, northern Mojave Desert: Bellingham, Western Washington University, M.S. thesis, 111 p.

Spencer, J.E., 1990, Geologic map of the southern Avawatz Mountains, northeastern Mojave Desert region, San Bernardino County, California: U.S. Geological Survey Miscellaneous Field Studies Map MF-2117, scale 1:24,000.

Wills, C.J., 1989a, Death Valley fault zone, Inyo and San Bernardino Counties, California: California Division of Mines and Geology Fault Evaluation Report FER-204, 17 p.

Wills, C.J., 1989b, A neotectonic tour of the Death Valley fault zone, Inyo County: California Geology, v. 42, no. 9, p. 195-200.

Workman, J.B., Menges, C.M., Page, W.R., Taylor, E.M., Ekren, E.B., Rowley, P.D., Dixon, G.L., Thompson, R.A., and Wright, L.A., 2002, Geologic map of the Death Valley ground-water model area, Nevada and California: U.S. Geological Survey Miscellaneous Field Studies MF-2381-A, 47 p., 1:250,000 scale.

Yount, J.C., Schermer, E.R., Felger, T.J., Miller, D.M., and Stephens, K.A., 1994, Preliminary geologic map of Fort Irwin Basin, north-central Mojave Desert, California: U.S. Geological Survey Open File Report 94-173, 27 p., scale 1:24,000. 


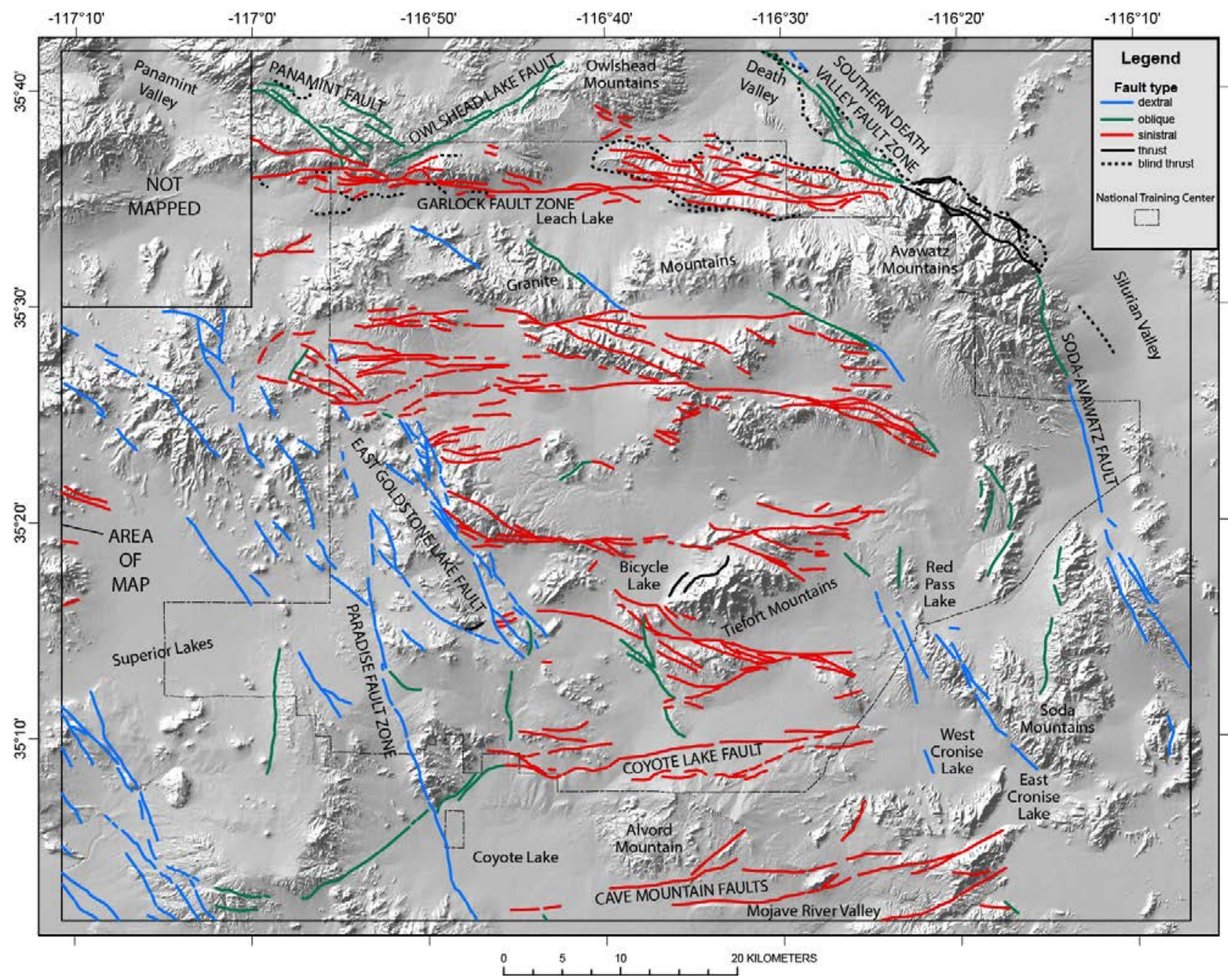

Figure 1. Generalized fault map for the Fort Irwin area on hillshade base map. Faults are colored according to dominant offset as shown in the legend. 